\title{
Herbivorous copepods with emphasis on dynamic Paracalanus quasimodo in an upwelling region
}

\author{
Judson da Cruz Lopes da Rosa ${ }^{1,2, *}$, Wanda Maria Monteiro-Ribas ${ }^{2}$, Lohengrin Dias de Almeida Fernandes ${ }^{2}$ \\ ${ }^{1}$ Universidade Federal Fluminense. \\ ${ }^{2}$ Instituto de Estudos do Mar Almirante Paulo Moreira. \\ (Instituto de Estudos do Mar Almirante Paulo Moreira, Departamento de Oceanografia, Divisão de Ecossistemas Marinhos. Rua Kioto, \\ 253, Laboratório de Plâncton; Praia dos Anjos; 28930000 - Arraial do Cabo, RJ - Brasil.) \\ *Corresponding author: judsoncruz@yahoo.com.br
}

\begin{abstract}
Coastal upwelling is known to transfer the nutrientrich water from the deep ocean to the surface, which benefits primary production and consequently increases local organic production. Cabo Frio is favored by the phenomenon and copepods are one of the groups most benefited. According to the results presented here, the higher abundances of Pacalanus quasimodo relative to other species are due to its rapid response to upwelling-dependent blooms. Therefore this study aims to assess the herbivory and dynamics of many copepod populations with emphasis on P. quasimodo. The results showed that temperature influences primary production, which in turn benefits the seston biomass ( $2=0.65, p=$ $0.008)$. The dominance of P. quasimodo was due to its emphasis on herbivory $(\mathrm{R} 2=0.83)$ and lead to a decrease in the planktonic diversity $(\mathrm{R} 2=0.63$, $p=0.002$ ). Our results revealed that predation by carnivorous copepods, like Corycaeus spp. and Oncaea spp. is the main opposing factor affecting P. quasimodo dominance. ( $\mathrm{R} 2=0.70, p=0.004$; $\beta$ predators $=0.41, p=0.04$ ).
\end{abstract}

Descriptors: Upwelling, Cabo Frio, copepods, Pacalanus quasimodo, Herbivorous.

\section{RESUMo}

A ressurgência transfere a água rica em nutrientes do fundo dos oceanos para a superfície, o que beneficia a produção primária e, consequentemente, aumenta a produção biológica local. Cabo Frio é favorecido pelo fenômeno e os copépodes são um dos grupos mais beneficiados. Os resultados mostraram que Pacalanus quasimodo foi a espécie mais abundante em relação às demais devido sua resposta rápida à floração. Assim, este estudo tem como objetivo avaliar a herbivoria e dinâmica das populações de copépodes, com ênfase em $P$. quasimodo. Os resultados mostraram que a temperatura influencia a produção primária, que, por sua vez, favorece a biomassa séston $(\mathrm{R} 2=0,65, p=$ 0,008). A dominância de $P$. quasimodo deveu-se à disponibilidade de alimento $(\mathrm{R} 2=0,83)$ e a elevada densidade da população leva a um decréscimo da diversidade $(\mathrm{R} 2=0,63, p=0,002)$. Nossos resultados revelaram que a predação por copépodes carnívoros, como Corycaeus spp. e Oncaea spp., é o principal fator que afeta a dominância de $P$. quasimodo (R2 $=0,70, p=0,004 ; \beta$ copépodes predador $=0,41, p=$ $0,04)$.

Descritores: Ressurgência, Cabo Frio, Copépodes, Pacalanus quasimodo, Herbívora. 


\section{INTRODUCTION}

Coastal regions cover at least $15 \%$ of the global ocean surface, and despite their short length (seu curto comprimento) these regions contribute about half of the overall primary production of the oceans. High productivity in coastal waters is due to their proximity to land, where runoff from rivers, atmospheric deposition, and groundwater can transport nutrients from the earth's land surface to the oceans. However, a large proportion ( $50 \%$ ) of productivity is attributable to coastal upwelling that transfers waters rich in nutrients from the deep ocean to the surface, fuelling primary production, the carbon cycle and the marine trophic web (MACKEY et al., 2012).

The complexity of the planktonic community is recognized as one of the main factors affecting micropelagic trophic interactions (ZARAUZ et al., 2009). This complexity is based upon the range of the size of a food to be consumed by an organism. For most mesozooplanktonic species ( $>200 \mu \mathrm{m})$, feeding is constrained by the morphology of the appendages that inhibit the consumption of small pikoplanktonic cells. Thus, energy is successively transferred through various increasing-size trophic levels up to top predators. The more trophic levels there are, the greater is the complexity and the lower the ecological efficiency of the system as a consequence of the energy lost as heat (SAUTOUR et al., 2000). Seasonally, upwelling brings new nutrients from deeper layers and fuels the growth of large cells such as Diatoms, which in turns speeds up the energy flow through the food web (SAUTOUR et al., 2000; FERNANDES et al., 2012).

We know that many organisms, such as barnacles and mussel larvae (FERNANDES et al., 2012), benefit from that increase in food availability, as also do copepods (BRANDINI et al., 1997), by synchronizing their reproductive peaks with the spring bloom of phytoplankton, which makes them an important target in the global scenario. Due to the geographical, meteorological and hydrological factors relating to Cabo Frio, the upwelling favors the microalgae bloom, influencing the marine food web in the region (FERNANDES et al., 2012). Paracalanus quasimodo is the most abundant herbivorous copepod in the region (BRANDINI et al., 1997) and is one of the top-down controllers of the growth of phytoplankton. This present study thus seeks to evaluate the herbivory and dynamics of copepod assemblies, but particularly focusing on the $P$. quasimodo population.

\section{MATERIAL AND METHODS}

Plankton samples were collected monthly on days of full moon as from January 2011, inclusive, at Cabo Frio Island, Cabo Frio, Brazil (238S 042.018W). Details of the study site can be found in GUENTHER et al. (2008). Data from January to December 2011 have been included herein. On each sampling date, three sub-surface (1 m depth) horizontal hauls of three minutes each were performed in sequence, giving a total of 36 samples (mesh size $100 \mu \mathrm{m}$, mouth opening $40 \mathrm{~cm}$ diameter). The phytoplankton biomass was estimated by Chlorophyll $a$ concentration $\left(\mathrm{mg} \mathrm{m}^{-3}\right)$ from water samples taken weekly $( \pm 1 \mathrm{~m}$ depth) using a Nansen bottle. Sea surface temperature (SST) was measured weekly using a reverse thermometer mounted on the Nansen bottle. Chlorophyll $a, b$, and $c$ were measured in accordance with PARSONS et al. (1984) Copepod abundance (ind $\mathrm{m}^{-3}$ ) was estimated from three sub-samples taken with a modified Stempel pipette $(2.68 \mathrm{ml})$ to a lower limit of 100 individuals (FRONTIER, 1981). All samples were weighed (wet weight) with a precision scale (10-5g) for calculation of seston biomass.

The community structure was described in terms of the Shannon-Weaver(H') diversity index and Pielou's evenness (J') (calculated only for adult copepods). In order to check the potential lagged and non-lagged relationship between sea surface temperature and Chlorophyll, the temperature data were shifted backwards up to 4 weeks. The same was done with the relationship between temperature and seston biomass. All effects were evaluated in accordance with a multilinear regression model. A linear regression analysis was performed relating temperature and P. quasimodo abundance, as also predatory copepods (Oncaea ssp. and Corycaeus ssp.) and P. quasimodo. A multiple regression analysis was performed in order to check the potential relationship between sea surface temperature, predators, and $P$. quasimodo. Herbivory was measured by means of the relationship between Chlorophyll $a$ concentration and the abundance of $P$. quasimodo but lagged by one week by means of a cross-correlation analysis (PIONTKOVSKI et al., 2006). The same analysis was performed as regards the relation between temperature and seston biomass.

\section{RESULTS}

Within the study period, temperature showed an overall average of $21.4^{\circ} \mathrm{C} \pm 2.1^{\circ} \mathrm{C}$. Temperature ranged in the area from $15^{\circ} \mathrm{C}$ to $25.8^{\circ} \mathrm{C}$. The average Chlorophyll $a$ was $1.05 \mathrm{mg} \mathrm{m}^{-3}$ and during the study ranged from 0 to 5.9 
$\mathrm{mg} \mathrm{m}^{-3}$. The total average of Chlorophyll was equal to 1.7 $\mathrm{mg} \mathrm{m}^{-3}$ and ranged from 0 to $8.8 \mathrm{mg} \mathrm{m}^{-3}$.

During the study period a total of 4 orders, 18 families and 39 taxa were identified and registered. The average density values $\left(7,597\right.$ inds. $\left.\mathrm{m}^{-3}\right)$ showed a high seasonality, with copepod peaks in July $\left(15,804 \pm 4,781\right.$ inds. $\left.\mathrm{m}^{-3}\right)$ and the lowest value in February $\left(1,923 \pm 718\right.$ inds. $\left.\mathrm{m}^{-3}\right)$. The peak of total chlorophyll occurs concomitantly with copepod peaks. Shannon diversity changed little throughout the year (annual average of $2.3 \pm 0.3$ bits.ind-1), with a minimum of 1.4 bits.inds $^{-1}$ in November and a maximum of 2.6 bits. ind-1 in June. The evenness also varied little throughout the year, with a minimum of 0.5 in November and 0.9 in June with a maximum annual average of $0.7 \pm 0.1$ (Figure 1). Paracalanus quasimodo presented the highest relative abundance (34\%) and frequency of occurrence (100\%) among all the copepod species found during the year. Other species that also stood out in terms of relative abundance were: Temora tubinata (14\%), Temora stylifera (4\%) Oncaea subitilis (2\%), Oncaea media (8\%), Paracalanus aculeatus (3\%), Oncaea venusta (2\%) Oithona nana (2\%), Oithona oswaldocruzi (2\%), Clausocalanus furcatus (2\%), and Corycaeus giesbrechti (1\%).
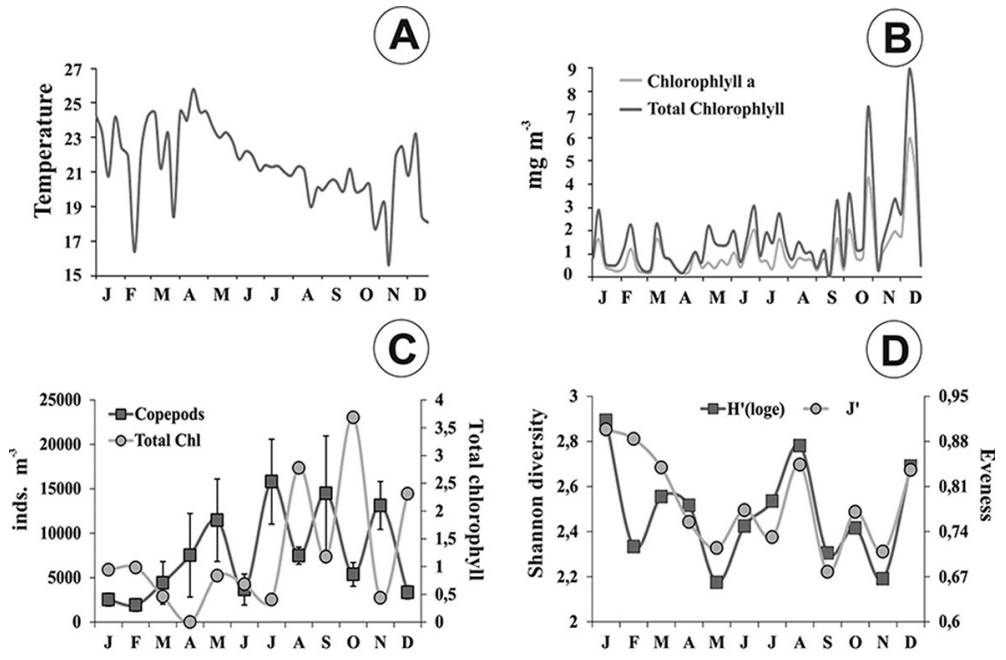

(E)

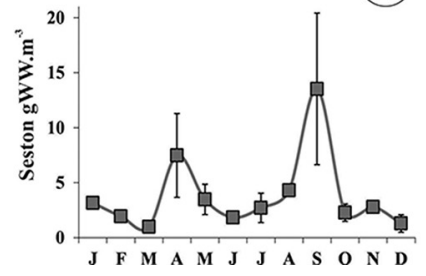

Figure 1. Weekly changes in temperature (A) and chlorophyll (B) during 2011; Monthly abundance of copepods superimposed on the monthly total chlorophyll biomass (C); Diversity and Equitability (D); Monthly changes in Seston Biomass (E).

The seston varied greatly over the year with a minimum of $0.9 \pm 0.09 \mathrm{gWW} \cdot \mathrm{m}^{-3}$ in March and a maximum of $13.5 \pm 6.8 \mathrm{gWW} \cdot \mathrm{m}^{-3}$ in September - with an average of $3.8 \pm 3.5 \mathrm{~g} \mathrm{WW} \cdot \mathrm{m}^{-3}$. Sea surface temperature was negatively correlated to the seston $(\mathrm{R} 2=0.65 ; p=0.008)$; and positively correlated to the Total Chlorophyll $(\mathrm{R} 2=$ $0.41 ; p=0.03$ ); but with a three-week lag (three weeks before). In general, any change in sea surface temperature and Chlorophyll was expected to influence the seasonal changes in seston biomass. The multiregressive model included both parameters as good predictors for the seasonal changes in seston $((\mathrm{R} 2 \mathrm{adj}=0.40, p=0.05)(\beta$ Chlorophyll $=0.41)(\beta$ Temperature $=-0.40))($ Table 1$)$.

The abundance of $P$. quasimodo had an annual average of $855 \pm 678$ ind. $\mathrm{m}^{-3}$ but showed a high intraannual variability, with a higher density in November (2731 ind. $\mathrm{m}^{-3}$ ) and a lower one in January (255 ind. $\mathrm{m}^{-3}$ ) (Table 2). Higher densities of $P$. quasimodo are positively cross-correlated to chlorophyll $a$, but one week lagged (R2 $=0.83, p<0.05)$. Females of $P$. quasimodo showed an annual average of 1208 inds. $\mathrm{m}^{-3}$, one order higher than male annual average (220 inds. $\mathrm{m}^{-3}$ ). As expected, both female and male densities were positively correlated, their

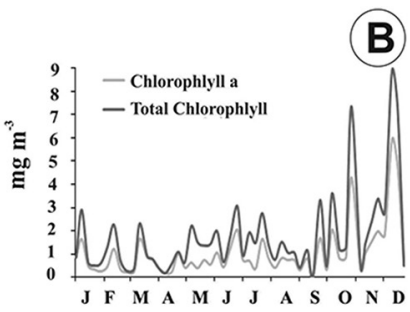


Table 1. Results of correlations and multiple regression.

\begin{tabular}{lc}
\hline Linear Regression & \\
\hline Temperature versus Seston & $\mathrm{R} 2=0.41, p=0.03$ \\
Total chlorophyll versus Seston & $\mathrm{R} 2=0.41, p=0.03$ \\
Multiple Regression & $\mathrm{R} 2=0.40, p=0.0508$ \\
BTotal chlorophyll & 0.41 \\
BTemperature & -0.40 \\
\hline
\end{tabular}

peaks occurring during the spring bloom $(\mathrm{R} 2=0.66, p=$ 0.001). Mostly during those peaks, $P$. quasimodo was the dominant species which led to a great decrease in pelagic diversity in the region ( $\mathrm{R} 2=0.63, p=0.002)$ (Figure 2). According to our results, P. quasimodo abundance is negatively correlated to the density of carnivorous copepods (e.g. Oncaea subitilis, Oncaea media, Oncaea venusta, Corycaeus giesbretis, Corycaeus ovalis, and Corycaeus speciosus) and also to temperature. Multiple Regression results suggested that predator copepods are responsible for controlling the density of $P$. quasimodo $(\mathrm{R} 2=0.70, p=0.004)(\beta$ predators $=0.41, p=0.04)$ (Figura 3).

\section{DISCUSSION}

The annual average temperature suggests the predominance of warm Tropical Water in the upper layer (200 m depth), especially during the austral autumn and winter, when the southwestern winds are unfavorable to the occurrence of upwelling (VALENTIN et al., 1987; LIMA et al., 1996; LORENZZETTI; GAETA, 1996). In contrast, from September to December, the cold nutrientrich South Central Atlantic Water is brought from a deep layer to near the surface and fuels primary productivity, increasing the chlorophyll in the region (e.g. BRANDINI et al., 1997; CARVALHO; GONZALEZ-RODRIGUEZ, 2004; FERNANDES et al., 2012).

Temperature is thought to influence the seston as has already been revealed in the study of VALENTIN and MOREIRA (1978) undertaken in the same region. The largest biomass of seston observed from November to April in both studies was associated with increases in phytoplankton and zooplankton abundances, that in turn were fuelled by upwelling. Both seston and temperature rhythms were correlated, even though our data revealed a delay in the seasonal peaks.

Some studies (e.g. SAUTOUR et al., 2000) reported the lack of energy available between phytoplankton standing stock and copepods, arguing that picophytoplankton is mostly preyed on by additional trophic levels such as heterotrophic flagellates, ciliates, and successively by mesozooplankton, that causes a great loss of energy during the transference to higher trophic levels. Other studies (e.g. CALBET et al., 2000; WIGGERT et al., 2005; RICHARDSON, 2008; UYE, 2010) defend the idea that copepods play an important role in energy flow following the classical trophic web, in which energy is transferred from phytoplankton to the higher trophic levels primarily throughout copepods. The copepod assembly in the region more closely resembles that of the classical food web. The higher copepod winter (July) density does not corroborate the conclusions of the work of MONTEIRO-RIBAS and MUREB (1991) undertaken in the same region, since higher abundances occurred in May (autumn).

All the disturbances that upwelling-downwelling rhythms represent in the region could impact the biodiversity. We found rapid changes in the diversity index, from a sudden increase relative to phytoplankton fueling to a subsequent decrease due to the $P$. quasimodo dominance. In general, January shows higher zooplankton diversity than do other months (BRANDINI et al., 1997), driven by the influence of the Tropical Water on the Brazilian shelf. A similar diversity index had previously been found by VALENTIN and MONTEIRO-RIBAS (1993) in the same region and some kind of dominance was also revealed.

In the coastal zone of Cabo Frio, as well as in other subtropical seas, copepods usually exhibit the highest relative abundance during most of the year (BRANDINI et al., 1997; VALENTIN; MONTEIRO-RIBAS, 1993; LIAO et al., 2006). Specifically in the Cabo Frio region, from 1974 to the present day, differences in the copepod assembly have revealed inter-annual changes in zooplankton structure, with the replacement of some frequent and abundant species, like Oncaea media, Paracalanus

Table 2. Paracalanus quasimodo density (inds. $\mathrm{m}^{-3}$ ), males and total population.

\begin{tabular}{lccccccccccccc}
\hline Months & J & F & M & A & M & J & J & A & S & O & N & D \\
\hline Female & 177 & 440 & 587 & 880 & 546 & 331 & 664 & 273 & 1111 & 367 & 1941 & 317 \\
Male & 78 & 50 & 65 & 81 & 143 & 72 & 432 & 203 & 330 & 278 & 789 & 114 \\
Total & 255 & 490 & 652 & 961 & 689 & 403 & 1095 & 476 & 1440 & 645 & 2731 & 431 \\
\hline
\end{tabular}



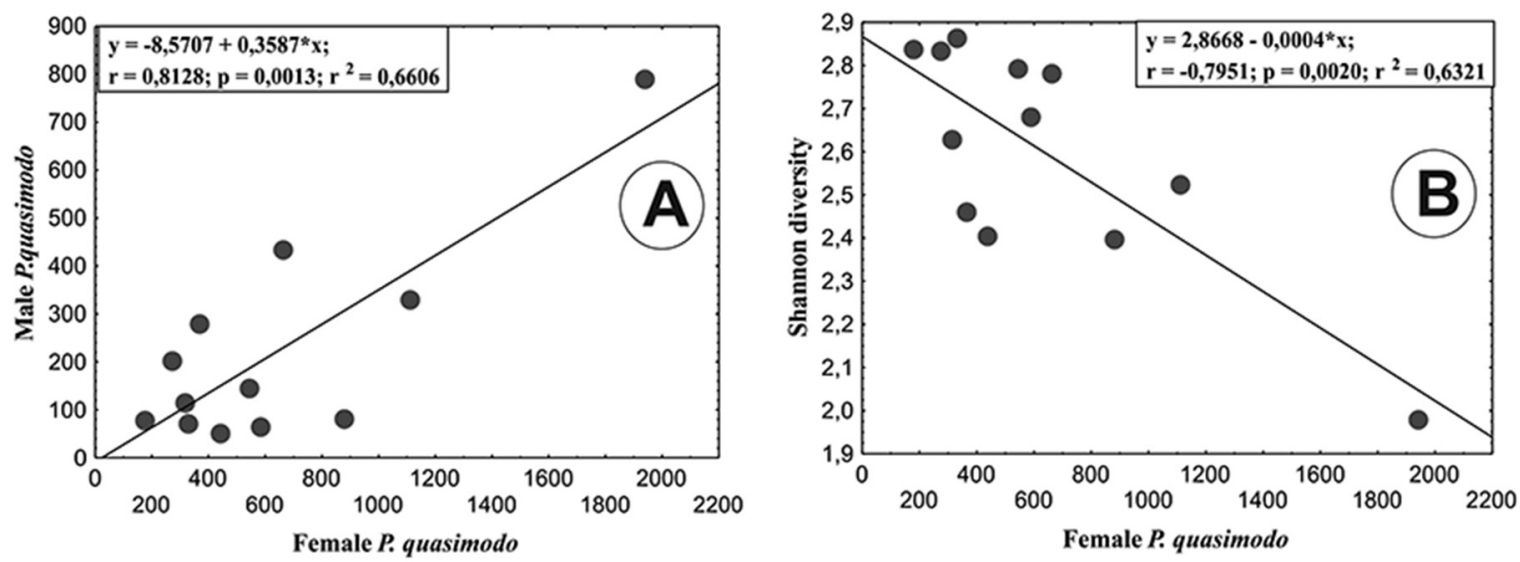

Figure 2. Correlation between Male and Femeia of P. quasimodo; Correlation analysis demonstrated that P. quasimodo is occasionally the dominant species and lead to a strong decrease in pelagic diversity (B)

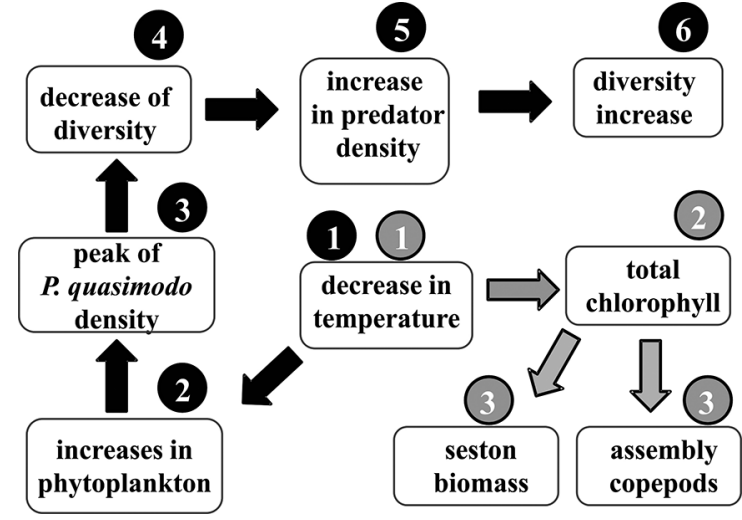

Figure 3. Black arrows - Dominance of P. quasimodo: (1) Upwelling event leading to a decrease in temperature and starting fueling phytoplankton; (2) increases in phytoplankton growth rate and consequent increase specifically in chlorophyll a after one weeks; (3) peak of P. quasimodo density in the following week and marked evidences of top-down control; (4) dominance of P. quasimodo and consequent decrease of diversity index; (5) increase in predator density (Oncaea media and Corycaeus giesbrechti) (6) the population of $P$. quasimodo decreases by higher-level top-down control and consequently relaxing phytoplankton grazing, and diversity increase back. Other copepod species benefits and diversity index increase back again.Gray - Absence of dominance: (1) Upwelling event leading to a decrease in temperature and starting fueling phytoplankton; (2) increases in the total chlorophyll $(\mathrm{a}+\mathrm{b}+\mathrm{c})$ followed in the next month (3) by an increase in whole copepod assembly density. Blue: The temperature three weeks before influences the seston by increasing the density mainly of the gelatinous groups, as salpa, doliolida, and jellyfish.

quasimodo, Microsetella sp, Euterpina acutifrons, Oncaea venusta, Calanoides carinatus, and Temora stylifera (MUREB et al., 1976), by others such as P. quasimodo, Oithona oculata, and E. acutifros (MONTEIRO-RIBAS; MUREB, 1991), in 1983. Currently P. quasimodo is still the dominant species. By contrast, over the years, species like $E$. acutifrons and $O$. oculata became less and less frequent/abundant. This succession of species with the passing of the years may be due to climate change, because copepods are very sensitive to any kind of physical and chemical change (RICHARDSON, 2008; KAARTVEDT, 2008). The lack of available information concerning those populations does not permit that we go further into details. Another factor that may also be influencing the composition of the assembly is the introduction of $T$. turbinata. This introduced species is well adapted to the environmental conditions found in the South Atlantic Ocean and is expanding its area of distribution along the Brazilian coast very rapidly (SANTOS et al., 2009). T. turbinata is a highly efficient competitor with the native species Temora stylifera (ARA, 2002) and probably also with $P$. quasimodo.

Paracalanus quasimodo was the species with the highest relative abundance in this study and this copepod has been cited as one of the most abundant species in coastal waters of Brazil (BRANDINI et al., 1997. Temperature was a factor that influenced the population density of P. quasimodo, according to our data. In Japan the genus Paracalanus reveals increases in population density at higher (summer) temperatures (TURNER, 2004). In Brazil, the species Paracalanus quasimodo has been mentioned as indicative of cold water (RESGALLA, 2011). This information corroborates the data presented herein, in accordance with which high abundances are concomitant with cold newly-upwelled waters. The adaptation of the genus Paracalanus to cold temperatures, means that adults, young and eggs may maintain a high density even in the presence of predators (TURNER, 2004). 
The bloom of large cells (mainly diatoms) during upwelling in the region benefits mesozooplankton grazing and increases ecological efficiency (FERNANDES et al., 2012). P. quasimodo was the copepod that benefited most from the peaks in chlorophyll, thus confirming the work of ESKINAZI and ANNA (2013) which referred to this species as one of the major top-controllers of primary production on the Brazilian coast. On a global scale, TURNER (2004) explains that the gender Paracalanus presents chemoreceptors and is able to perceive the cells over long distances and at low concentrations. This opportunistic herbivore can attain rapid growth rates induced by pulses of autotrophic biomass, typical in areas of bloom (GUENTHER et al., 2008).

A recent study (DRILLET et al., 2011) has shown that over experimental time females tend to live longer than males, and that fecundity does not appear to be affected in old females due to their ability to store sperm.

Oncaea media was one of the highly abundant copepods found during this study and the Family Oncaeidae is considered to be highly abundant worldwide (METZ, 1998). In Brazil it is found all along the coast in the surface with temperatures between 15 and $21^{\circ} \mathrm{C}$ and salinity of 35 (DIAS; ARAUJO, 2006). The occasional reduction of the density of the $P$. quasimodo population may be due to the predation of adults and nauplii by Oncaea and Corycaeus species. According to TURNER (2004) those copepods are usually carnivores and may feed on other copepods and nauplii. Previous studies in the same region have revealed that $P$. quasimodo and $O$. media density is related to the occurrence of upwelling, while Corycaeus giesbrechti is more abundant in periods of downwelling (MUREB et al., 1976). In this study the population of $P$. quasimodo was controlled by these predators both during upwelling and subsidence. In the absence of these predators, the density of P. quasimodo increases considerably. Globally, predators usually feed more often on the dominant prey, leading to an increase in the density of rare species and thus enhancing diversity (RICKLEFS, 2010).

\section{CONCLUSION}

The copepod assembly in upwelling regions is closely influenced by phytoplankton dynamics throughout the year. The population of $P$. quasimodo was the one that stood out as a herbivore mainly as a result of the influence of upwelling and in the absence of their predators (Oncaea and Corycaeus). When this species stands out in terms of relative abundance it affects the entire dynamic of the assembly, thus decreasing diversity.

\section{ACKNOWLEDGEMENTS}

The author wishes to thank those who worked on the sampling and laboratory analysis, mainly the Chemical Group of IEAPM, and also the staff of the Department of Oceanography. We would also thank FAPERJ Fundação Carlos Chagas Filho de Amparo à Pesquisa do Estado do Rio de Janeiro for their financial support (E26/110.220/2011) and training scholarship and technical training (enrollment - 2011.3807.5)

\section{REFERENCES}

ARA, K. Temporal variability and production of Temora turbinata (Copepoda: Calanoida) in the Cananéia Lagoon estuarine system, São Paulo, Brazil. Sci. Mar., v. 66, n. 4, p. 399-406, 2002.

BRANDINI, F. P.; LOPES, R. M.; GUTSEIT, K. S. Planctonologia na plataforma continental do Brasil: diagnose e revisão bibliográfica. Rio de Janeiro: MMA, CIRM, FEMAR, 1997.

CALBET, A.; LANDRY, M. R.; SCHEINBERG, R. D. Copepod grazing in a subtropical bay: Species-specific responses to a midsummer increase in nanoplankton standing stock. Mar. Ecol. Prog. Ser., v. 193, p. 75-84, 2000.

CARVALHO, W. F. DE; GONZALEZ-RODRIGUEZ, E. Development of primary and bacterial productivity in upwelling waters of Arraial do Cabo region, RJ (Brazil). Braz. J. Oceanogr., v. 52, n. 1, p. 35-45, 2004.

DIAS, C. O.; ARAUJO, A. V. Copepoda. In: BONECKER, S. L. C. Atlas do zooplâncton da Região Central da Zona Econômica Exclusiva. Série Livros. Rio de Janeiro: Museu Nacional, 2006. p. 23-101.

DRILLET, G.; FROUËL, S.; SICHLAU, M. H.; JEPSEN, P. M.; HØJGAARD, J. K. Status and recommendations on marine copepod cultivation for use as live feed. Aquaculture, v. 315, n. 3/4, p. 155-166, 2011.

ESKINAZI, E.; ANNA, S. Remains of the protozoan sticholonche zanclea in the faecal pellets of Paracalanus quasimodo, Parvocalanus crassirostris, Temora stylifera and Temora turbinata (copepoda, calanoida) in Brazilian coastal waters. Braz. J. Oceanogr., v. 61, n. 1, p. 73-76, 2013.

FERNANDES, L. D. A.; QUINTANILHA, J.; MONTEIRORIBAS, W.; GONZALEZ-RODRIGUEZ, E.; COUTINHO, R. Seasonal and interannual coupling between sea surface temperature, phytoplankton and meroplankton in the subtropical south-western Atlantic Ocean. J. Plankton Res., v. 34, n. 3, p. 236-244, 2012.

FRONTIER, S. Diseño de muestreos. In: BOLTOVSKOY, D. (Ed). Atlas del zooplancton del Atlántico Sudoccidental y métodos de trabajo con el zooplancton marino. Mar del Plata: INIDEP, 1981. p. 103-108. 
GUENTHER, M.; GONZALEZ-RODRIGUEZ, E.; CARVALHO, W. F.; REZENDE, C. E.; MUGRABE, G.; VALENTIN, J. L. Plankton trophic structure and particulate organic carbon production during a coastal downwelling-upwelling cycle. Mar. Ecol. Prog. Ser., v. 363, p. 109-119, 2008.

KAARTVEDT, S. Photoperiod may constrain the effect of global warming in arctic marine systems. J. Plankton Res., v. 30, n. 11, p. 1203-1206, 2008.

LIAO, C. H.; CHANG, W. J.; LEE, M. A.; LEE, K. T. Summer distribution and diversity of copepods in upwelling waters of the Southeastern East China Sea. Zool. Stud., v. 45, n. 3, p. 378-394, 2006.

LIMA, I. D.; GARCIA, A. E. C.; MÖLLER, O. O. Ocean surface processes on the southern Brazilian shelf: characterization and seasonal variability. Cont. Shelf Res., v. 16, n. 10, p. 1307-1317, 1996.

LORENZZETTI, J. A.; GAETA, S. A. The Cape Frio upwelling effect over the South Brazil Bight northern sector shelf waters: a study using AVHRR images. Int. Arch. Photogram. Remote Sens., v. 31, p. 448-453, 1996.

MACKEY, K. R. M.; MIONI, C. E.; RYAN, J. P.; PAYTAN, A. Phosphorus cycling in the red tide incubator region of Monterey Bay in response to upwelling. Front. Microbiol., v. 33, p. 1-14, 2012.

METZ, C. Feeding of Oncaea curvata (Poecilostomatoida, Copepoda). Mar. Ecol. Prog. Ser., v. 169, p. 229-235, 1998.

MONTEIRO-RIBAS, W. M.; MUREB, M. A. Larvas de mexilhão o Perna perna (LINNÉ, 1758)) em Arraial do Cabo (RJ). Nerítica, v. 6, p. 27-41, 1991.

MUREB, M. A.; MONTEIRO-RIBAS, W.; PESSOTTI, E.; VALENTIN, J. O. O plâncton na ressurgência de Cabo Frio (Brasil). VII. Os copépodos (período de 21/06/1973 a 28/02/1974). Rio de Janeiro: Instituto de Pesquisa da Marinha, 1979. p. 1-15.

PARSONS, T. R.; MAITA, Y.; LALLI, C. M. A manual of chemical and biological methods for seawater analysis. Oxford: Pergamon press, 1984.

PIONTKOVSKI, S. A.; O’BRIEN, T. D.; UMANI, S. F.; KRUPA, E. G.; STUGE, T. S.; BALYMBETOV, K. S.; GRISHAEVA, O. V.; KASYMOV, A. G. Zooplankton and the North Atlantic Oscillation: a basin-scale analysis. J. Plankton Res., v. 28, n. 11, p. 1039-1046, 2006.
RESGALLA JÚNIOR, C. The holoplankton of the Santa Catarina coast, southern Brazil. An. Acad. Bras. Ciênc., v. 83, n. 2, p. 575-588, 2011.

RICHARDSON, A. J. In hot water: Zooplankton and climate change. ICES J. Mar. Sci., v. 65, n. 3, p. 279-295, 2008.

RICKLEFS, R. E. A economia da natureza. 6. ed. Rio de Janeiro: Guanabara Koogan, 2010. p. 366-382.

SANTOS, T. G.; GUSMÃO, L. M. O.; NEUMANN-LEITÃO, S.; CUNHA, A. G. Zooplâncton como indicador biológico da qualidade ambiental nos estuários dos rios carrapicho e botafogo, itamaracá - PE. Rev. Bras. Eng. Pesca, v. 4, n. 1, p. 44-56, 2009.

SAUTOUR, B.; ARTIGAS, L. F.; DELMAS, D.; HERBLAND, A.; LABORDE, P. Grazing impact of micro-and mesozooplankton during a spring situation in coastal waters off the Gironde estuary. J. Plankton Res., v. 22, n. 3, p. 531-552, 2000.

TURNER, J. T. The importance of small pelagic planktonic copepods and their role in pelagic marine food webs. Zool. Stud., v. 43, n. 2, p. 255-266, 2004.

UYE, S. Human forcing of the copepod-fish-jellyfish triangular trophic relationship. Hydrobiologia, 666, 71-83, 2010.

VALENTIN, J. L.; ANDRE, D. L.; JACOB, S. A. Hydrobiology in the Cabo Frio (Brazil) upwelling two-dimensional structure and variability during a wind cycle. Cont. Shef Res., v. 7, p. 77-88, 1987.

VALENTIN, J. L.; MOREIRA, A. P. A matéria orgânica de origem zooplanctônica nas águas da ressurgência de Cabo Frio (Brasil). An. Acad. Bras. Ciên., v. 50, n. 1, p. 103-112, 1978.

VANLENTIN, J. L.; MONTEIRO-RIBAS, W. M. Zooplankton community structure on the east-southeast Brazilian continental shelf $\left(18-23^{\circ} \mathrm{S}\right.$ latitude). Cont. Shelf Res., v. 13, n. 4, p. 407-424, 1993.

WIGGERT, J. D.; HASKELL, A. G. E.; PAFFENHÖFER, G. A.; HOFMANN, E. E.; KLINCK, J. M. The role of feeding behavior in sustaining copepod populations in the tropical ocean. J. Plankton Res., v. 27, n. 10, p. 1013-1031, 2005.

ZARAUZ, L.; IRIGOIEN, X.; FERNANDES, J. A. Changes in plankton size structure and composition, during the generation of a phytoplankton bloom, in the central Cantabrian sea. J. Plankton Res., v. 31, n. 2, p. 193-207, 2009. 
